\title{
Kepribadian Ekstrofet Tokoh Dalam Novel Pudarnya Pesona Cleopatra Karya Habiburrahman El-Shiarzy Kajian Psikoanalisis
}

\author{
Maftuhah \\ Sekolah Tinggi Ilmu Tarbiyah Muhammadiyah Paciran, Indonesia \\ Email: Kireina1704@gmail.com
}

Abstract: This research describes a personality of a character's extrofet which is implied by the study of psychoanalysis put forward by Sigmund Freud in Habiburrahman El-Shirazy's Faded Pesona Cleopatra novel. The problems that the writer will study are: 1. How are the personality forms of the character's extrofet in the novel Pudarnya Pesona Cleopatra by habiburrahman el-shirazy which includes (1) the main character or I, (2) the raihana character or wife of the main character, (3) the mother character, (4) the figure of yaqulbi, and (5) the figure of yasmin or the wife of yaqulbi and 2. How is the personality description of the character's extrophette based on the psychoanalytic study of Sigmund Freud in the novel Pudarnya Pesona Cleopatra by Habiburrahman El-Shiarzy. Research conducted on the novel Fading Pesona Cleopatra results in that in all activities of life the personality of a character is always based on three principles as said by Sigmund Freud namely Id, Ego, and Super Ego. These three principles are the principle of constant, pleasure principle and the reality principle contained in human life.

Keywords: Extrophet Personality and Psychoanalysis Study.

\section{Pendahuluan}

Karya sastra sebagai potret kehidupan bermasyarakat merupakan suatu karya sastra yang dapat dinikmati, difahami, dan dapat dimanfaatkan oleh masyarakat. Karya sastra tercipta karena adanya pengalaman batin pengarang berupa peristiwa atau problem dunia yang menarik, sehingga muncul gagasan imajinasi yang dapat dituangkan dalam bentuk karya sastra. Karena karangan fiksi yang berupa novel.

Kepribadian merupakan bagian dari karya sastra. Menurut Gordon W. Allport (dalam Pradja, 2013, p.20) kepribadian merupakan 
sebuah organisasi yang dinamis dari sistem psikofisik individu yang turut menentukan tingkah laku dan pemikiran individu secara khas. Untuk bisa memahami sebuah kepribadian seseorang adalah dengan mencoba mengenal seseorang melalui struktur kepribadianya berdasarkan tokoh.

Menurut Jung ada dua aspek penting dalam kepribadian yaitu sikap dan fungsi. Sikap terdiri atas Introvet dan Ekstrofet, sedangkan fungsi terdiri atas thinking, feeling, sensing, dan intuiting. Jung juga menyebutkan bahwa dominasi dari salah satu sikap dan fungsi diatas, sebagai suatu tipe psikoanalisis karena kepribadian manusia merupakan pengalaman tertekan, dan memori manusia yang tersimpan akan dihimpun dalam alam ketidaksadaran.

Kepribadian ekstrofet berkaitan dengan sikap jiwa manusia terdiri dari beberapa tipe yaitu pikiran, perasaan, pendirian, dan intuisi. Pada hakikatnya psikoanalisis sastra itu juga meneliti jiwa manusia, yakni pengarang dan pembaca, Tokoh dalam karya sastra hadir sebagai representasi dari keadaan jiwa penciptanya yang dituangkan melalui kepribadianya dari para tokoh tersebut. Psikoanalisis diintegrasikan dalam ilmu pengetahuan sebab psikoanalisis memusatkan perhatianya pada satu realitas tentang ketidaksadaran sebagai satu proses kepribadian ekstrofet. Melihat hubungan psikoanalisis dengan karya sastra sehingga dalam konteks ini psikoanalisis digunakan sebagai salah satu alat analitis atau alat kritik dalam penelitian untuk menganalisis suatu kepribadian ekstrofet tokoh.

Teori psikoanalisis Sigmund Freud didalamya membahas tentang alam bawah sadar (alam mimpi), dan alam sadar seseorang untuk menganalisis sebuah kepribadian ekstrofet. Kajian psikoanalisis dan sastra dalam masa perkembanganya juga dapat dikelompokkan menjadi beberapa bagian yaitu: bagian-bagian (1) psikonalisis klasik 
(sigmud freud) atau psikologi Id, psikologi Ego, dan psikologi Super Ego, (2) teori psikoanalisis tentang relasi - objek, (3) psikoanalisis struktural, (4) psikoanalisis yang berhubungan dengan ideologi, dan (5) psikoanalisis dari kaum feminisme. Pada penelitian ini penulis menggunakan bagian psikoanalisis klasik (sigmund freud) atau psikologi Id, psikologi Ego, dan psikologi Super Ego.

\section{Landasan Teori}

Teori dasar yang mendukung penelitian analisis Kepribadian Ekstrofet Tokoh dalam novel Pudarnya Pesona Cleopatra karya Habiburrahman El-Shirazy kajian Psikoanalisis. Teori-teori tersebut merupakan teori-teori pendukung yang digunakan sebagai acuan penelitian. Acuan teori-teori ini hanya digunakan untuk memahami konsep dasar penelitian yang berkaitan dengan judul, teori-teori dasar tersebut meliputi: Novel adalah sebuah bentuk cerita yang tertulis dan naratif. Biasanya dalam bentuk cerita, penulis novel di sebut dengan novelis. Atau dapat dikatakan bahwa novel adalah karangan prosa panjang yang melukiskan suatu peristiwa kehidupan tokoh cerita yang akhirnya terjadi perubahan hidup pada tokoh tersebut (Zora, 22 oktober 2012).

Secara garis besar menurut Nurgiyantoro (2010, p.23) unsurunsur pembangun novel dapat dikelompokan menjadi dua bagian yaitu unsur instrinsik dan unsur ekstrinsik. Kedua unsur inilah yang sering banyak disebut para kritikus dalam rangka mengkaji atau membicarakan karya sastra pada umumnya.

Unsur intrinsik adalah unsur-unsur yang secara langsung yang ikut serta membangun sebuah cerita dari dalam novel. Sebuah novel akan terwujud dengan baik jika antara unsur instrinsik saling terkait dan padu. Unsur-unsur intrinsik yang dimaksud yaitu (1) tema, (2) 
penokohan, (3) alur, (4) latar, (5) sudut pandang, (6) amanat, (7) gaya bahasa.

Sedangkan, Unsur ekstrinsik adalah unsur-unsur yang berada diluar karya sastra tetapi secara tidak langsung mempengaruhi bangunan atau sistem organisme karya sastra. Secara lebih khusus dapat dikatakan sebagai unsur-unsur yang mempengaruhi bangunan cerita dalam sebuah karya sastra namun tidak ikut sendiri menjadi bagian didalamnya. Unsur ekstrinsik cukup berpengaruh terhadap totalitas bangun cerita yang dihasilkan, oleh karena itu unsur ekstrinsik sebuah novel haruslah tetap dipandang sesuatu yang penting Nurgiyantoro (2010:23).

\section{Pengertian Kepribadian}

Gordon Allport (dalam Wilcox, 2013:266) meneliti bahwa definisi kepribadian yang digunakan dalam psikologi menemukan hampir 50 definisi berbeda yang berhasil dikategorikan, salah satu kategori menyebut kepribadian sebagai reaksi orang lain terhadap individu yang menentukan kepribadiaanya. Kategori lain menjelaskan bahwa kepribadian adalah segala sesuatu yang dianggap penting tentang individu.

Seperti juga halnya karya sastra, maka kepribadian pun mempunyai jenis-jenis dan unsur-unsur. Unsur yang turut menentukan keutuhan kepribadian Menurut Koenjaraningrat (2009, p.82) adalah unsur-unsur dari kepribadian meliputi Pengetahuan, Perasaan, Dan Dorongan Naluri.

\section{Kepribadian Ekstrofet Tokoh}

Sangat berkaitan dengan analisis sebuah karya sastra terutama yang berhubungan dengan analisis sebuah novel. Sehingga pada bagian ini yang penulis bahas dari kepribadian ekstrofet tokoh meliputi: 
Pengertian Kepribadian Ekstrofet, Pengertian Tokoh, Dan Kepribadian Ekstrofet Tokoh.

Berikut ini uraianya 1. Pengertian kepribadian ekstrofet, Menurut Carl Gustav Jung (dalam Baihaqi, 2013, p.23) banyak dari kesadaran manusia pada saat kita mengamati dan bereaksi terhadap dunia ditentukan oleh sikap ekstraversi dan sikap introversi. Kedua sikap ini merupakan cara yang berlawanan dalam melihat dunia, keduanya merupakan bagian yang sangat terkenal dalam teori jung pada umumnya, psikologi secara keseluruhannya telah menerima secara baik kedua sikap ini. 2. Pengertian tokoh, Menurut Stanton (dalam Susanto, 2012, p.132) istilah tokoh memiliki beberapa cara pemakaian yang berbeda yang pertama, tokoh digunakan untuk menunjukan pada orang-orang yang terdapat dalam sebuah cerita atau sebagai contoh jumlah orang yang ada dalam cerita yang disajikan kedua, istilah tokoh digunakan untuk menjelaskan bagaimana lukisan atau gambaran watakwatak dari para tokoh tersebut, 3. Kepribadian Ekstrofet Tokoh, Berdasarkan beberapa pendapat di atas dapat disimpulkan bahwa kepribadian Ekstrofet Tokoh adalah sesuatu yang mempunyai fungsi atau arti adaptasi yang menentukan keadaan jiwa dan sikap jiwa seseorang.

Psikoanalisis merupakan sebuah kajian yang kebanyakan dipergunakan dalam sebuah penelitian karya sastra. Pada penelitian ini penulis menggunakan kajian psikoanalisis untuk menganalisis tokoh lewat kepribadian ekstrofet. Sehingga pada bagian ini yang penulis bahas mengenai psikoanalisis meliputi: Pengertian Psikoanalisis, Psikoanalisis Dan Sastra, Psikonalisis Sastra. Berikut ini penjelasanya:

1. Pengertian psikoanalisis, Menurut Susanto (2012, p.47) Psikoanalisis pada dasarnya memiliki beberapa pengertian, yakni 
sebagai praktik psikologis, sebagai bentuk praktik akademik, dan sebagai satu teori.

2. Psikoanalisis dan Sastra, hubungan psikoanalisis dan sastra sangat berkaitan, karena psikoanalisis merupakan suatu ilmu yang dipergunakan untuk mengkaji jiwa seseorang. Dalam dunia sastra pengarang menggunakan ilmu psikoanalisis untuk bisa menuangkan ide-ide cerita kedalam sebuah karya sastra terutama yang berbentuk novel dengan cara memperankanya sebagai seorang tokoh.

3. Psikoanalisis Sastra, merupakan sebuah hubungan yang yang tidak bisa dipisahkan karena psikoanalisis merupakan sebuah kajian ilmu yang masuk dalam dunia sastra melalui para ilmuwan-ilmuwan sastra.

\section{Teori Kepribadian Psikoanalisis Sigmund Freud}

Struktur kepribadian menurut Freud (dalam Pradja, 2013, p.56) bahwa kehidupan jiwa manusia memiliki tiga tingkat kesadaran yaitu sadar (conscious), prasadar (preconscious), dan tidak sadar (unconscious). Sampai dengan tahun 1920-an teori tentang konflik kejiwaan hanya melibatkan ketiga unsur di atas, kemudian pada tahun 1923 Freud mengenalkan model struktur yang lain yaitu Id (das es), Ego (das ich), dan Super Ego (das ueber ich). Berikut ini pengertian dari Id, Ego, dan Super Ego.

1. Id. Aspek ini adalah aspek biologis dan merupakan system yang orisinil didalam kepribadian dari aspek inilah kedua aspek yang lain tumbuh (Sujianto, 2006, p.60).

2. Ego, Aspek ini adalah aspek psikologis dari pada kepribadian dan timbul karena kebutuhan organisme untuk berhubungan secara baik dengan dunia kenyataan atau realitas (Sujianto, 2006, p.61), 
3. Super Ego, lebih merupakan kesempurnaan daripada kesenangan, Super Ego dapat pula dianggap sebagai aspek moral daripada kepribadian.

Dalam penelitian ini penulis menggunakan dua pendekatan yaitu pendekatan psikologi dan pendekatan struktural.

1.Pendekatan psikologis yang banyak bersandar kepada psikoanalisis, yang dikembangkan Freud setelah melakukan berbagai penelitian, Bahwa manusia banyak dikuasai oleh alam batinya sendiri,

2. Pendekatan kedua yang penulis gunakan adalah pendekatan struktural yang paling utama dan pertama kali dilakukan adalah menguasai pengertian-pengertian dasar dan semua kompenen yang membangun struktur sebuah karya sastra dalam hal ini yang paling penting untuk dianalisis adalah unsur intrisnsiknya.

Kepribadian Ekstrofet Tokoh dalam Novel Pudarnya Pesona Cleopatra Karya Habiburrahman El-Shirazy Kajian Psikoanalisis.

Analisis kepribadian ekstrofet tokoh dalam novel pudarnya pesona Cleopatra karya habiburrahman el-shirazy kajian psikoanalisis tersebut dimulai dengan mengumpulkan data yang berupa novel karya habiburrahman. Yang mana memilih berdasarkan teori yang ungkapkan oleh Sigmund Freud. Kemudian data tersebut dikelompokkan atau diklasifikasi berdasarkan bentuk-bentuk kepribadian ekstrofet tokoh dan teori kepribadian psikoanalisis yang dikemukakan oleh Sigmund

Freud. Setelah itu data dianalisis sesuai rumusan yang terdapat pada setiap paragraf yang sudah dikelompokkan.

Bentuk-bentuk kepribadian ekstrofet tokoh dalam novel Pudarnya Pesona Cleopatra ada tiga yaitu 1. Pikiran, 2. Perasaan, 3. Pendirian, 4. Intuisi yang dispesifikasikan dalam lima tokoh di bawah ini: (1) Tokoh Utama, dalam novel Pudarnya Pesona Cleopatra di atas, 
menunjukan bahwa keadaan jiwa tokoh Utama atau Aku pikirannya sangat penuh dengan khayalan dan angan-angan. Tokoh Aku hanya memandang gadis dari kecantikannya. Kecantikan gadis Mesir sangat mempesona wajah dan auranya sangat berkilau, (2) Tokoh Raihana, dalam novel Pudarnya Pesona Cleopatra di atas, menunjukan bahwa jiwa dan batin Raihana sangat tersiksa. Raihana sangat tersiksa dengan perlakuan suaminya yang dihadapi dalam kehidupan sehari-hari. Akan tetapi, Raihana menanggapinya dengan perasaan dan perlakuan yang sabar hanya tangisan yang bisa diutarakan Raihana untuk menutupi kesakitan dan kekecewaan hatinya, (3) Tokoh Ibu, dalam novel Pudarnya Pesona Cleopatra di atas, menunjukan bahwa Ibu dari tokoh Utama sangat menyayangi anak-anaknya apapun akan dilakukan oleh Ibu demi kebahagiaan anaknya. Demi membahagiakan anak tertuanya tokoh Ibu menjodohkan atau mencarikan pasangan yang baik buat anaknya dan keluarganya nanti. Anaknya dijodohkan dengan anak dari teman tokoh Ibu saat di pesantren dulu, namanya Raihana dia adalah gadis yang sholehah dan dari keluarga yang baik-baik dan sholehah, (4) Tokoh Yaqulbi, dalam novel Pudarnya Pesona Cleopatra di atas, merupakan teman dari tokoh Utama dan mempunyai istri yang bernama Yasmin. Yasmin adalah seorang gadis mesir yang cantik jelita. Saat menikah dengan Yasmin pak Yaqulbi merasa tertekan karena selama hidup bersama Yasmin pak Yaqulbi selalu tersakiti. Keadaan tersebut membuat hati pak Yaqulbi merasa menyesal karena ketika menikah dengan Yasmin pak Yaqulbi hanya melihat dari kecantikannya saja, (5) Tokoh Yasmin, hanya memikirkan kesenangan-kesenangan dunia saja. Ia berfikir bahwa kekayaan dan kemewahan bisa membuat hidup menjadi bahagia. Yasmin pun bertekat untuk meminta cerai dari suaminya. Yasmin tidak punya kesadaran sama sekali. 
Gambaran kepribadian tokoh menurut Sigmund Freud yaitu: 1 . Identitas diri dari para tokoh berisikan aspek psikologis yang diturunkan seperti insting, implus dan drive tetapi, Identitas diri para tokoh tidak mempunyai implus karena prinsip kenikmatannya adalah keadaan yang tidak relatif yaitu berupa kepuasan dalam khayalan. Khayalan dan kepuasan terlalu berperan dalam kehidupan para tokoh, terutama tokoh Aku dan tokoh Yaqulbi yang teropsesi pada kecantikan gadis Mesir. Disinilah tokoh Aku dan para tokoh lainya merasakan rasa sakit yang menimbulkan tegangan atau peningkatan energi Sehingga, bersikap seperti tidak mempunyai sikap moral dalam kehidupan nyata nya. Sehingga, Muncullah Sifat Ego., 2. Ego, dalam hal Ego terlihat bagaimana prinsip ksenangan yang terdapat dalam diri tokoh Utama dan tokoh tambahan lainya yaitu dalam alam prasadarnya berusaha mencari kesenangan tetapi hal yang dilakukannya merupakan dalam alam tak sadarnya karena prinsip realitas yang dikontrol oleh Ego dalam diri masing-masing tokoh. Sistem kepribadian yang tidak membedakan antara dunia khayalan dan kenyataan. 3. Super Ego,

Tokoh-tokoh dalam novel Pudarnya Pesona Cleopatra, dijelaskan bahwa berdasarkan karakter fisiologis, psikologis, dan sosiologis bersifat dinamis. Pembentukan dan perubahan karakter terjadi karena dipengaruhi oleh faktor usia, pengalaman hidup, ilmu yang dimiliki, dan tujuan hidup yang hendak dicapai.

\section{Kesimpulan}

Berdasarkan analisis Kepribadian Ekstrofet Tokoh dalam novel Pudarnya Pesona Clepatra Karya Habiburrahman El-Shirazy Kajian Psikoanalisis terdapat beberapa kesimpulan yaitu: 1. Bentuk-bentuk kepribadian ekstrofet yang dimilki lima tokoh meliputi tokoh Utama, tokoh Raihana, tokoh Ibu, tokoh Yaqulbi, tokoh Yasmin yang ada dalam novel pudarnya pesona Cleopatra terdiri dari empat bentuk 
yaitu: (1) Pikiran, (2) Perasaan, (3) Pendirian, (4) Intuisi. 2. Gambaran kepribadian yang dialami lima tokoh dalam novel Pudarnya Pesona Cleopatra berdasarkan Sigmund Freud terdiri tiga elemen yaitu: (1) Id, (2) Ego, dan (3) Super Ego.

\section{Daftar Rujukan}

El- Shirazy, Habiburrahman. 2007. Pudarnya Pesona Cleopatra. Jakarta: Penerbit Republika.

Freud, Sigmund. 2009. Pengantar Umum Psikoanalisis Sigmund freud. Yogyakarta: Pustaka Pelajar.

http://id.wikipedia.org/wiki/kepribadian\#cite_note_kepribadian1 (diakses 30 Maret 2014)

http://monamarianinovel.wordpress.com/december/18/2012 (diakses 30 Maret 2014)

http://nauzora.blogsport.com/2012/10/jenis-jenis-novel.html (diakses 7 Maret 2014)

http://wordhealt-blogsport.com/2012/05/teori-kepribadianmenurut-carl-gustaf-html. (diakses 10 April 2014)

Koenjaranigrat. 2009. Antropologi Edisi Revisi. Jakarta: PT. Rineka Cipta. (diakses 31 Mei 2014).

Nurgiyantoro, Burhan. 2010. Teori Pengkajian Fiksi Burhan Nurgiyantoro. Yogyakarta: Gadjah Mada University Press. Pradja, dkk. 2013. Psikologi Kepribadian (Lanjutan) Studi Atas Teori Dan Tokoh Psikologi Kepribadian. Bandung: Pustaka Setia.

See more at: http://mediaonlinenews.com/pengembangan-diri/6-Tipe-

Kepribadian-Manusia-Menurut-John-L-

Holland\#sthash.tX4IUBDb.dpuf (diakses 20 April 2014)

See more at: http://mediaonlinenews.com/pengembangan-diri/7-Tipe Kepribadian-Manusia-Menurut-GerartHeymans\#sthash.GUAIRqbZ.dpuf (diakses 20 April 2014)

See more at: http://mediaonlinenews.com/pengembangan-diri/TipeKepribadian-Manusia-Menurut-EduardSpranger\#sthash.3Fq555p3.dpuf (diakses 20 April 2014)

Sujianto, dkk. 2006. Psikologi kepribadian. Jakarta: Bumi Aksara. Susanto, Dwi. 2012. Pengantar Teori Sastra. Yogyakarta: PT. buku Seru.

Wilcox, Lynn. 2013. Psikologi Kepribadian. Diterjemahkan Oleh P. Kumalahadi. Jogjakarta: IRCiSoD 